\section{The influence of health educa- tion about the true position of breastfeeding for post partum mothers in the Pepe Village, Indonesia}

\author{
Fauziyatun Nisa, \\ Shrimarti Rukmini Devi \\ Doctoral Program of Public Health, \\ Faculty of Public Health Universitas \\ Airlangga, Indonesia
}

\begin{abstract}
Breastfeeding is a natural process in which pregnant mothers will be breastfeeding to help their babies stay healthy. However, several factors can interfere with appropriate breastfeeding, such as family income, mothers' knowledge about breastfeeding and supportive environment. This study aimed to identify the effect of health education on maternal behavior in breastfeeding techniques. The design of this study was one-group pre-post design. 122 postpartum mothers were chosen as samples in this study by simple random sampling technique. Data was collected using observation sheets, and then analyzed by using Wilcoxon signed rank test with a significance level of $\alpha=0.05$. The results showed that there was a significant effect of health education on maternal behavior in breastfeeding techniques with a result of $p$ value of 0.000 . It is hoped that all postpartum mothers can follow breastfeeding techniques with a proper positioning, ensure proper latching on to the nipples, so breastfeeding can be a comfortable and pain-free experience both for mothers and the babies.
\end{abstract}

\section{Introduction}

Breast milk is the first food that infants received; it provides all energy and nutrients needed for babies during the first few months of life. It continues to provide up to half or more of the nutritional needs of children during the second six months of life and one third during the second year of life. ${ }^{1}$ Based on Indonesia National Basic Health Data in 2010, it was explained that $67.5 \%$ of mothers who failed to breastfeed exclusively for their babies happened because lack of understanding about appropriate breastfeeding techniques. Common problems related to proper breastfeeding techniques include nipple blisters, swollen breasts, and breast abscess which is commonly called as mastitis. ${ }^{2}$
Postpartum mothers often felt difficulties in giving appropriate breastfeeding. They did not have adequate knowledge about the importance and strategies in giving breastfeeding. Knowledge is the dominant factors that influence the practices of breastfeeding. In fact, not all women produce enough milk, with regards to their physical or psychological conditions. Problems arise when mothers felt exhausted, anxious, or depressed, during breastfeeding. ${ }^{3}$

In general, mothers will express breast milk 8-10 times every 24 hours with a maximum break of five hours. As breast milk contains antibacterial and antiviral components, by giving it regularly to their babies, will lower the risk of transmitting infectious diseases, such as colds and flu, ear and respiratory tract infections, and diarrhoea. ${ }^{4,5}$

Mothers should give breastfeeding exclusively for their babies in the first 6 months in order to achieve optimal growth, development and health. Complementary foods with adequate nutrition could be given after the first 6 months and up to 2 years of age. ${ }^{6}$

Based on preliminary data, mothers were found to give very short or extremely long breastfeeding but baby did not receiving enough milk due to ineffective suckling or low milk production. It was observed that their babies still seem hungry after the feedings. They have problems with latch-on and positioning at the breast. It was often that babies missed breastfeeding as they sleeps through the night. Several mothers experienced severe breast engorgement due to poor breastfeeding latch and positioning. Mothers also did not give breast milk when they have severe nipple pain, as the nipples cracked and bleeding after breastfeeding. ${ }^{7}$

Health education provides positive opportunities for mothers to increase their knowledge in breastfeeding techniques. Health education can improve mothers' attitudes and behavior as well as families, special groups and communities. Through a health education program, mothers will be supported and reassured to give breastfeeding. Health education will be focused more on the initiation of breastfeeding how to manage their breastfeeding difficulties. ${ }^{8,9}$

This study aims to determine the effect of health education on maternal behavior in correct breastfeeding techniques in postpartum mother.

\section{Materials and Methods}

The design of this study was one-group pre-post design. 122 post-partum mothers were chosen as samples in this study by
Correspondence: Fauziyatun Nisa, Doctoral Program of Public Health, Faculty of Public Health, Universitas Airlangga, Jl. Mulyorejo, Surabaya, Jawa Timur 60115, Indonesia. Tel.: +62.31.5920948 - Fax: +62.31.5924618 E-mail: fauziyatun.nisa-2018@fkm.unair.ac.id

Key words: health education, true position breastfeeding, multipara.

Acknowledgments: the authors would like to thank all respondents in this study.

Contributions: the authors contributed equally.

Conflict of interest: the authors declare no potential conflict of interest.

Funding: none.

Clinical trials: the study is not involved any clinical trials.

Conference presentation: part of this paper was presented at the $3^{\text {rd }}$ International Symposium of Public Health, 2018 October 31 - November 1, Universitas Airlangga, Surabaya, Indonesia.

Dedication: the article is dedicated to Doctoral Program of Public Health, Faculty of Public Health, Universitas Airlangga, Surabaya, Indonesia

Received for publication: 28 July 2019.

Revision received: 9 September 2019.

Accepted for publication: 15 October 2019.

This work is licensed under a Creative Commons Attribution NonCommercial 4.0 License (CC BY-NC 4.0).

(C) Copyright: the Author(s), 2019

Licensee PAGEPress, Italy

Journal of Public Health in Africa 2019; 10(s1):1209 doi:10.4081/jphia.2019.1209

simple random sampling technique. Data was collected using observation sheets and then analyzed by using descriptive statistics in the form of frequency distribution tables. Wilcoxon signed rank test was used to measure the effect of health education on maternal behavior in correct breastfeeding techniques in post-partum mother with a significance level of $\alpha=0.05 .3,10$

\section{Results and Discussion}

Mother's position to correct breastfeeding techniques before being given health education

Based on Table 1, it was obtained the 
most mothers (68.7\%) had less appropriate breastfeeding techniques before giving health education. Results showed that most mothers (68.7\%) had less appropriate breastfeeding techniques before giving health education. This happens because most of post-partum mothers do not know appropriate breastfeeding techniques and never received health education about how to breastfeed properly, the benefits of giving breast milk to their babies and how to give maximum breast milk. Most mothers had a problem with incorrect positioning and positioning their babies and causes nipple blisters, as well as decreased in breast milk production.

Factors that affect appropriate breastfeeding techniques are age, education and experiences. Commonly, the older the mothers then they have more experience in giving breastfeeding. Other factors which were found in the study include lack of mothers' knowledge about how to give a proper breastfeed, lack of information from health workers to mothers, lack of clarity of information, lack of understanding about the importance of breastfeeding. Mothers who had higher level of education will be easier to receive information.

\section{The position of mothers about breastfeeding techniques after being given health education}

Based on Table 2, it showed that almost all mothers (95\%) had a good knowledge of breastfeeding techniques after giving health education. Most post-partum mothers after being given health education became more aware of proper breastfeeding techniques, so that it can be said that the results of health education have been successful. The aim of health education is to bridge the gap between health information and health practices, which motivates a person to obtain information and do something so that he can keep him/herself healthier by avoiding bad habits and forming good habits for health. ${ }^{14}$

Table 1. Distribution of frequency of mother's position about breastfeeding before health education was given to normal post partum mothers in Pepe Sedati Village $(n=122)$.

\begin{tabular}{lcc}
\hline Position & Frequency & $\%$ \\
Good & 0 & 0.0 \\
Enough & 38 & 31.3 \\
\hline Less & 84 & 68.7 \\
Total & 122 & 100.0 \\
\hline
\end{tabular}

Table 2. Distribution of frequency of mother's position about breastfeeding after health education was given to normal post partum mothers in Pepe Sedati Village $(n=122)$.

\begin{tabular}{lcc} 
Position & Frequency & $\%$ \\
Good & 116 & 95.0 \\
Enough & 6 & 5.0 \\
\hline Less & 0 & 0.0 \\
Total & 122 & 100.0 \\
\hline
\end{tabular}

Table 3. Effect of health education on correct breastfeeding position in postpartum mothers in Pepe Sedati Village.

\begin{tabular}{lccccc}
\hline Information & Result & N & Mean rank & Nilai Wilcoxon & P Value \\
Position before $<$ position after & Negative & 0 & 0.00 & -5.379 & 0.000 \\
Position before $>$ position after & Positive & 116 & 19.50 & & \\
\hline Position before $=$ position after & Ties & 6 & & & \\
Total & & 122 & & & \\
\hline
\end{tabular}

Mother's position about breastfeeding techniques before and after doing breastfeeding techniques correctly

Based on Wilcoxon test, there was a significant effect of health education on maternal behavior in breastfeeding techniques with a result of $p$ value of 0.000 (Table 3 ). Health education was found to be effective in providing emotional support for mothers. Health education improved mothers' attitudes and breastfeeding practices. $8,9,11$ Health education provides factual information, encourage mothers to adopt appropriate breastfeeding practices and learn new skills to manage breastfeeding issues. Health education is an effective strategy in the promotion of breastfeeding practices among post-partum mothers. Health education improved mothers' knowledge of breastfeeding, attitude to and practice of breastfeeding. Thus, health care professionals should promote and support post-partum mothers to breastfed their babies. Health education program related to breastfeeding practices also includes how to feed the babies during the day and night and when to do the weaning. Families and relatives are urged to provide support and motivation to lactating mothers for successful initiation and maintenance of breastfeeding. Health care professionals should always monitor and evaluate breastfeeding practices in the community. ${ }^{12-14}$

\section{Conclusions}

It can be concluded that there was a significant effect of health education on maternal behavior in breastfeeding techniques with a result of $p$ value of 0.000 .

\section{References}

1. Austutik RY. Payudara dan laktasi. Jakarta Selatan: Salemba Medika; 2014.

2. Sulistyawati. Asuhan Kebidanan pada ibu nifas. Yogyakarta: CV Andi offset; 2009.

3. Notoatmodjo S. Pendidikan dan perilaku kesehatan. Jakarta: Rineka Cipta; 2003.

4. American Academy of Pediatrics. Breastfeeding and the Use of Human Milk. Pediatrics 2005;129:827-41.

5. Purwanti HS. Konsep penerapan Asi ekslusif: buku saku untuk bidan. Jakarta: EGC; 2004.

6. Kristiyansari W. ASI, Menyusui dan Sadari. Yogyakarta: Maha Medika; 2011.

7. Suprayoprajogo N. Keajaiban 
Menyusui. Yogyakarta: Keyword; 2009.

8. Nursalam. Konsep dan penerapan metodologi penelitian ilmu keperawatan (pedoman skripsi, tesis, dan instrumen penelitian. Jakarta: Salemba Medika; 2008.

9. Mulyani. Asi dan panduan ibu menyusui. Yogyakarta: Nuha Medika; 2013.

10. Notoatmodjo S. Metodologi penelitian kesehatan. Jakarta: Rineka Cipta; 2009.
11. Oktaviani PD. Hubungan Tingkat Pengetahuan ibu tentang cara menyusui dengan praktik ibu menyusui 2016. Surakarta: Universitas Muhammadiyah Surakarta; 2009. Available from: http://v2.eprints.ums.ac.id/archive/etd/4 3571. Accessed on: 11 August 2018.

12. Mulya R, Rachmawati IN. Gambaran Pola Pemberian ASI Pada Ibu Bekerja Pada Komunitas Pendukung ASI 2013. Available from: http://lib.ui.ac.id
/naskahringkas/2016-03/S47139Rahayu\%20Mulya. Accessed on: 11 August 2018.

13. Nursalam, Pariani S. Pendekatan Praktis Metodologi Riset Keperawatan. Jakarta: Sagung Seto; 2001.

14. Pariani S, Nursalam. Metodologi Riset Keperawatan. Jakarta: Sagung Seto; 2001. 